\title{
CAPTAÇÃO DOS RECURSOS HÍDRICOS E REUTILIZAÇÃO DA ÁGUA EM UMA RESIDÊNCIA
}

Nome do Autor (a) Principal

Gabriel Lima Barbosa

Nome (s) do Coautor (a) (s)

Renata Cristina Oliveira Santos; Ana Maria Castro Machado.

Nome (s) do Orientador (a) (s)

Profa. Dra. Camila Pires Cremasco Gabriel

Profa. Dr. Luís Roberto Almeida Gabriel Filho

Instituição ou Empresa

Universidade Estadual Paulista "Júlio de Mesquita Filho"

Instituição (s) de Fomento

UNESP - Campus de Tupã

E-mail de contato: glbarbosa3105@gmail.com

Palavras-chave: Água. Reutilização. Sustentabilidade

1 INTRODUÇÃO

A água por ser um recurso natural tem grande importância, sendo essencial à vida, ao desenvolvimento econômico e ao bem-estar social. A quantidade de água que se encontra na natureza não muda, ou seja, permanece constante em rios, lagos, oceanos e geleiras espalhadas pelo mundo. Entretanto, a poluição e contaminação da água provoca diminuição progressiva do volume de água potável disponível para consumo (Tucci et. al., 2001).

O semiárido é uma região que sofre com as frequentes secas que castigam milhares de pessoas, sendo necessários diversos tipos de adaptações e estratégias 


\section{Periódica Eletrânica

para conviver com a seca. Para isso se tornar possível é necessário a utilização de tecnologias eficazes de captação e armazenamento de água.

A reutilização de água de casas surge como uma opção pratica no intuito fazer um ciclo de reutilização da agua que constantemente vem apresentando tecnologias avançadas e apropriadas para seu emprego. A importância do incentivo da prática do reuso em regiões semiáridas, por ser uma alternativa de fonte de suprimento de água disponível, evitando o lançamento de efluentes de estações de tratamento em rios.

De maneira geral, as residências na região semiárida, assim como nas demais regiões do Brasil são construídas de modo convencional, agredindo o meio ambiente e sem preocupações com o seu potencial de captação de água da chuva e da reutilização (VIEIRA et. Al, 2013). Portanto, este trabalho tem o objetivo de construir uma residência autossustentável possuindo um grande potencial de captação de água da chuva e estratégias de reuso da água que circula na própria residência.

\section{OBJETIVO GERAL}

Este trabalho tem o objetivo de construir uma residência autossustentável possuindo um grande potencial de captação de água da chuva e estratégias de reuso da água que circula na própria residência.

\section{OBJETIVOS ESPECÍFICO}

\section{Reutilização da água}

Por conta da distribuição desigual da água no país, muitas vezes, onde há água, não há tanta gente, por exemplo, na Amazônia, e onde há muita gente não há tanta disponibilidade hídrica, como na Região Sudeste do país. A reutilização da água precisa seguir critérios básicos, como por um exemplo a segurança da saúde, estética, proteção ambiental e viabilidade técnica e econômica (Carneiro, et. Al, 


\section{Periódica Eletrânica

2010). Uma forma que se destaca é o tratamento de esgoto de processos industriais, como os de produtos de carvão, produção primária de metal, químicas, de papel e celulose.

Outra forma é a conjugação do aproveitamento da água da chuva captada em telhados e calhas com o reuso das águas que derivam de uso doméstico ou comercial, como de chuveiros, banheiros, banheiras, tanques, máquinas de lavar roupa e vai direto para um sistema de abastecimento paralelo ao da água potável.

\section{Drenagem sustentável}

A drenagem sustentável visa facilitar a penetração da água da chuva no solo por meio de técnicas capazes de diminuir o volume das enxurradas, além de tratar parte da poluição difusa presente na enxurrada (ANDOH, et. al. 1995).

O uso de pavimentos permeáveis é tido como uma das principais técnicas de drenagem sustentável. Basicamente, este sistema é composto de uma série de elementos vazados que, quando assentados, permitem que a água penetre nos espaços vazios e atinja o solo.

\section{METODOLOGIA}

Relativamente à reutilização da agua, tem uma importância considerável no estudo que incide sobre o uso da água em casas sustentáveis. Neste sentido, foram realizadas experiências que apontam para a viabilidade do processo.

Por outro lado, o fato do volume de água que será gasto em cada descarga ou em afazeres domésticos pode ser elevado, isto leva à realização de experiências que permitam averiguar qual a quantidade de água realmente necessária para o efeito satisfatório do reaproveitamento de agua além de economizar a mesma.

Será utilizado para a drenagem um telhado verde, que deverá ser preparado com impermeabilização e sistemas de drenagem para receber o telhado. Em casos de estruturas que já foram executadas sem o planejamento para receber o telhado, deverá ser feito um estudo para analisar a carga que pode ser colocada ou até 


\section{Periódica Eletrânica

mesmo fazer um reforço estrutural. O cuidado com o crescimento das raízes também é um fator muito importante, motivo pelo qual um especialista poderá indicar as espécies adequadas a cada situação.

\section{RESULTADO}

Como a redução dos gastos dos meios hídricos em geral, não só beneficia toda a população e sim ecossistema inteiro que vive em torno desse sistema de reutilização da agua (Carneiro, et. al. 2010). Com intuito de diminuir desperdício de água em residências também se obtém a redução de impactos ambientais, a despoluição dos rios e lagos da região podemos citar como exemplo já que evita a retirada de recursos hídricos do solo e além de favorecer o consumidor com redução da conta de água, fazendo com que se crie um habito de economizar e reutilizar a água.

Além de baixo custo e simples de implantar e utiliza matérias reutilizáveis sendo assim uma outra forma de reduzir impactos ambientais.

\section{CONSIDERAÇÕES FINAIS}

Conclui-se que é necessário difundir tecnologias sustentáveis na área da construção civil, qualificar e aperfeiçoar profissionais especializados para desenvolver inovações tecnológicas na visando ações efetivas que utilizem o aproveitamento dos recursos renováveis.

\section{REFERENCIAS}

Tucci, C. E. M. Gestão da água no Brasil. Brasília: UNESCO, 2001.

VIEIRA, Carine Cristina. Aproveitamento de águas pluviais: influência do volume de descarte e da filtração na qualidade da água. 2013. 70 f. Trabalho de Conclusão de Curso (Graduação) Universidade Tecnológica Federal do Paraná, Curitiba, 2013.

ANDOH, R.Y.G. \& SMISSON, R.P.M. (1995). Alternative Urban drainage strategy utilising the single pipe system. Anais $\mathrm{Da}$ 2nd International Conference on Innovative Technologies in Urban Storm Drainage, p189-196, Lyon, França.

Carneiro, André Luiz Aguiar, and Edgarde Gonsalves Cerqueira. "APROVEITAMENTO DA ÁGUA DA CHUVA E PROVENIENTE DO ESGOTO SECUNDÁRIO (AGUAS CINZAS).", 2010. 